\title{
How can we conserve cold stenotherm communities in warming Alpine ponds?
}

\author{
Christiane Ilg $\cdot$ Beat Oertli
}

Received: 12 November 2012/ Accepted: 28 April 2013/Published online: 23 May 2013

(C) Springer Science+Business Media Dordrecht 2013

\begin{abstract}
Freshwater biodiversity has shown to be highly vulnerable to climate warming, alpine cold stenotherm populations being especially at risk of getting extinct. This paper aims at identifying the environmental factors favouring cold stenotherm species in alpine ponds. This information is required to provide management recommendations for habitats restoration or creation, needed for the mitigation of the effects of climate warming on alpine freshwater biodiversity. Cold stenotherm species richness as well as total (i.e. stenotherm and eurytherm) richness were analyzed for aquatic plants, Coleoptera and Odonata in 26 subalpine and alpine ponds from Switzerland and were related to environmental factors ecologically relevant for pond biodiversity. Our results confirmed that the set of environmental variables governing pond biodiversity in alpine or subalpine ponds is specific to altitude. Altitude and macrophyte presence were important
\end{abstract}

Guest editors: R. Céréghino, D. Boix, H.-M. Cauchie, K. Martens \& B. Oertli / Understanding the role of ponds in a changing world

Electronic supplementary material The online version of this article (doi:10.1007/s10750-013-1538-1) contains supplementary material, which is available to authorized users.

C. Ilg $(\bowtie) \cdot$ B. Oertli

hepia Geneva Technology, Architecture and Landscape, University of Applied Sciences Western Switzerland, 150 route de Presinge, 1254 Jussy, Geneva, Switzerland e-mail: christiane.ilg@hesge.ch drivers of cold stenotherm and total species richness, whereas connectivity did not show any significant relation. Therefore, the management of pond biodiversity has to be 'altitude-specific'. Nevertheless, cold stenotherm species from the investigated alpine ponds do not show some specific requirements if compared to the other species inhabiting these ponds. Therefore, both total and cold stenotherm species richness could be favoured by the same management measures.

Keywords Small waterbodies - Climate warming and altitude $\cdot$ Boreo-alpine species · Aquatic plants . Aquatic beetles $\cdot$ Dragonflies

\section{Introduction}

Alpine ecosystems are especially vulnerable to climate change (Krajick, 2004). Alpine species distribution is often closely linked to climate (Yoccoz et al., 2010) and therefore even small changes in temperature or precipitation may result in large changes in species composition and biodiversity (Sala et al., 2000). Several studies already reported upward shifts in plant species distributions as a response to climate warming (Parolo \& Rossi, 2008; Vittoz et al., 2008). A similar trend is also expected in alpine ponds, and the upward migration of plants, invertebrates and amphibians from lowland could lead to a strong increase of species richness (Rosset et al., 2010). In the same time, cold 
stenotherm species may be unable to adapt to changing climatic conditions and risk local extinction (Woodward et al., 2010). For ponds in the Swiss Alps, Rosset \& Oertli (2011) identified 22 aquatic vascular plant species, 13 beetles (Dytiscidae) species and seven dragonfly species as cold thermal specialists, being highly sensitive to climate warming. Potential answers of these species to warming are either migration to higher altitudes or extinction. However, migration success is widely dependent on the host capacity of the newly colonized areas.

The main environmental parameters favouring biodiversity in lowland ponds are well-known, including for example pond size, water quality, unimpaired catchment, diversity of habitats (e.g. drawdown zone, depth, aquatic vegetation), shoreline characteristics (design, slopes, islands, trees), presence of fish, connectivity with other ponds and wetlands (Biggs et al., 1994; Gee et al., 1997, Oertli et al., 2000), providing pointers for pond creation and management (Williams et al., 1999, Oertli \& Frossard, 2013). However, until recently, less information was available on the environmental factors influencing alpine waterbodies biodiversity (Füreder et al., 2006). In the frame of the EU project EMERGE (Catalan et al., 2009a), biota diversity in alpine lakes has been studied in relation to local, regional and biogeographical factors to use these ecosystems as indicators of climate change. The influences of environmental factors such as altitude and physico-chemistry on species richness and distribution were assessed for several taxonomic groups throughout Europe (Füreder et al., 2006; Fjellheim et al., 2009; Mendoza \& Catalan, 2010). However, little attention was paid to the cold stenotherm species, although they are the most susceptible to climate change due to their narrow niche breadth (Thuiller et al., 2005).

Therefore it is important to identify the environmental parameters favouring these cold stenotherm species to identify, protect, restore or create suitable habitats and mitigate the effects of climate change on alpine freshwater biodiversity.

The aims of this study conducted on ponds from Switzerland are therefore to:

(1) assess the local (pond scale) species richness patterns of cold stenotherm communities along the altitudinal gradient (from lowland to alpine area),
(2) identify key environmental variables driving the local species richness of the cold stenotherm species.

Therefore, in order to better evidence the specificity of the ecological requirements of the cold stenotherm communities, it will also be necessary: (i) to compare species richness patterns of these cold stenotherm species with the trends observed for the global species richness (all species, i.e. including also eurytherms and other stenotherms), (ii) to investigate the relations between environmental variables and species richness also in lowland ponds.

\section{Methods}

A total of 26 ponds located in the subalpine and alpine altitudinal belt (1,400-2,800 $\mathrm{m}$ above sea level) in the Swiss Alps were studied. The ponds were widespread over the $25,000 \mathrm{~km}^{2}$ of the Swiss Alps, covering four biogeographical regions (Appendix 1 in Supplementary material). The area of the waterbodies varied between $112 \mathrm{~m}^{2}$ and 9.5 ha.

An additional set of 60 lowland ponds was investigated in the framework of previous studies (e.g. Oertli et al., 2000, 2002) and sampled with the same standardized procedure. These data will be used here for comparison of lowland with alpine and subalpine patterns (e.g. altitudinal patterns of species richness).

\section{Species richness}

Three taxonomic groups (aquatic plant, Coleoptera Dytiscidae and Odonata) were selected. These taxonomic groups are known to be good biotic indicators of pond biodiversity (Oertli et al., 2005) and include several cold thermal specialist species as defined by Rosset \& Oertli (2011). Aquatic plant, Dytiscidae and Odonata were assessed using the PLOCH standardized sampling methods (Oertli et al., 2005) once at each pond between 1996 and 2002. Aquatic invertebrates were sampled using a net (mesh size $0.5 \mathrm{~mm}$ ). The number of samples was proportional to the area of the pond and distributed in the main mesohabitats. Adult dragonflies were surveyed using a standardized field method. Additional information on the presence (and autochthony) of Odonata was provided through the larvae captured among the macroinvertebrate samples. 
The inventory of the aquatic plants was carried out in quadrats, the number of them being proportional to the pond area.

Species were recognized as "cold stenotherm" on the basis of the cold thermal specialist species list proposed by Rosset \& Oertli (2011) (Appendix 2 in Supplementary material) who used thermal preferences and resilience to warming to assess their sensitivity to climate warming.

\section{Environmental variables}

From more than hundred environmental variables measured in field or calculated from spatial analyses (Oertli et al., 2005), a subset of 11 variables, known to be potentially drivers for alpine pond biodiversity, was selected (Hinden et al., 2005; Oertli et al., 2008; Martínez-Sanz et al., 2012) (Appendix 1 in Supplementary material). The choice included: biogeographical regions based on Gonseth et al. (2001), area (log transformed), altitude, connectivity calculated following Humbert-Droz (2000), water conductivity, number of mesohabitats (Oertli et al., 2005), the presence of fishes, the presence of macrophytes (submerged and floating aquatic plants) and the presence of helophytes. Two environmental parameters related to land cover in the $50 \mathrm{~m}$ surroundings of the pond were also selected: percentage of grassland ( $\%$ grassland) and rock (\% rock) cover.

\section{Data analysis}

Relations between cold stenotherm species richness (as well as total species richness) and environmental variables were assessed using Spearman correlation tests for continuous environmental variables and by mean of non-parametric Kruskall-Wallis tests for categorical environmental variables. For altitude, both total (stenotherm and eurytherm) and cold stenotherm species richness of each taxonomic group were assessed along the whole Swiss elevation gradient.

Altitude can be seen as a complex combination of related climatic variables (Sharma et al., 2009) and is therefore correlated with numerous other environmental parameters. Half of the investigated environmental parameters were strongly linked to altitude: conductivity, connectivity, $\%$ rock, as well as the presence of helophytes and macrophytes. For these variables we used the residualized variables i.e. the residuals obtained from linear and logistic regressions of these variables with altitude, in order to remove the effects of altitude. Likewise, a residualized fish variable obtained from logistic regression with area was used instead of fish presence which was connected to area.

Significant relations were investigated further by means of generalized additive models (GAMs, Hastie \& Tibshirani, 1990). GAMs were carried out in R (R Development Core Team, 2012) using the GRASP package (Lehmann et al., 2002). This package allows a stepwise model selection procedure to select variables to be retained in the final model. A quasi-Poisson family was used for the response variables to accommodate under- or over-dispersion.

\section{Results}

Biodiversity in the 26 alpine and subalpine ponds

Aquatic plants were present in $81 \%$ of the investigated ponds, whereas beetles (Dytiscidae) and dragonflies were present in 69 and $65 \%$ of the ponds, respectively (Table 1).

Cold stenotherm species were less frequent: plant and Odonata species could be detected with slightly lower frequencies, respectively 77 and $65 \%$ of the ponds, whereas cold stenotherm Dytiscidae species occurred with a markedly lower frequency, only in $35 \%$ of the ponds.

The number of species of cold stenotherm specialists per pond varied among the taxonomic groups (Table 1). The total number of plant species per pond was high (mean: 5.6 species), whereas Odonata and Dytiscidae showed lower total numbers of species per pond (means: respectively 1.5 and 1.3). For the cold stenotherm species plants showed the highest number of species per pond (mean: 1.5 species), whereas the number of Odonata and Dytiscidae species was lower (means: respectively 0.8 and 0.5 species).

The abundance (number of individuals per pond) was also lower for cold stenotherm species, and especially marked for dragonflies (Table 1).

Species richness patterns along the altitudinal gradient

Along the whole Swiss altitudinal gradient (including lowland ponds), the total species richness of the three 
Table 1 Number of species (mean, minimum and maximum) and abundance (fauna: number of individuals, mean, minimum and maximum; flora: percentage of occurrence in the quadrats per species, mean, minimum and maximum) per pond, as well as incidence (\%) in 26 alpine and subalpine ponds from Switzerland

\begin{tabular}{|c|c|c|c|c|c|c|c|}
\hline & Incidence & $\begin{array}{l}\text { Mean species } \\
\text { number }\end{array}$ & $\begin{array}{l}\text { Minimum } \\
\text { species number }\end{array}$ & $\begin{array}{l}\text { Maximum } \\
\text { species number }\end{array}$ & $\begin{array}{l}\text { Mean } \\
\text { abundance }\end{array}$ & $\begin{array}{l}\text { Minimum } \\
\text { abundance }\end{array}$ & $\begin{array}{l}\text { Maximum } \\
\text { abundance }\end{array}$ \\
\hline \multicolumn{8}{|c|}{ Cold stenotherm species } \\
\hline Plants & 77 & 1.5 & 0 & 4 & 4.89 & 0 & 71.4 \\
\hline $\begin{array}{l}\text { Coleoptera } \\
\text { Dytiscidae }\end{array}$ & 35 & 0.5 & 0 & 2 & 9.6 & 0 & 163 \\
\hline Odonata & 65 & 0.8 & 0 & 2 & 32 & 0 & 250 \\
\hline \multicolumn{8}{|c|}{ All species (eurytherms + stenotherms) } \\
\hline Plants & 81 & 5.6 & 0 & 24 & 2.6 & 0 & 84.4 \\
\hline $\begin{array}{l}\text { Coleoptera } \\
\text { Dytiscidae }\end{array}$ & 69 & 1.3 & 0 & 4 & 14.2 & 0 & 163 \\
\hline Odonata & 65 & 1.5 & 0 & 6 & 253.9 & 0 & 5581 \\
\hline
\end{tabular}

taxonomic groups decreased sharply at higher altitude (Fig. 1). The cold stenotherm species richness, was, on the contrary, positively correlated with altitude for all studied taxonomic groups. However, inside the subalpine and alpine altitudinal range investigated, the number of cold stenotherm plant and Odonata species was also negatively correlated with altitude (Table 2).

Relation between species richness

and environmental variables

The range of the observed values was wide for all continuous variables measured in the 26 alpine and subalpine ponds (Appendix 1 in Supplementary material). Only few of the relationships between cold stenotherm species richness and the environmental variables were significant (Table 2). Cold stenotherm plant species richness was correlated with only one of the environmental parameters: the number of cold stenotherm plant species varied significantly between the different biogeographical regions, with plant species richness being higher in the northern Alps. The Dytiscidae were also characterized by biogeographical significant discrepencies: their species richness was higher in Engadine. The number of cold stenotherm Dytiscidae species increased with altitude and rock cover but was negatively correlated with pond area and helophyte presence. Cold stenotherm Odonata richness was on the contrary negatively correlated to altitude but positively related to the presence of macrophytes.
The GAM models (Table 3; Fig. 2) confirmed the importance of the altitude which was retained as predictive variable in all cold stenotherm richness models. Macrophyte presence was retained in the Dytiscidae and the Odonata models. However if the Odonata richness increased with the presence of macrophytes, Dytiscidae richness rather followed an unimodal response curve. The nonlinearity of the relationship explains why it was not detected by the correlation tests. As already detected by means of correlation tests, area was a significant predictor for Dytiscidae species richness, whereas a rocky environment was retained only in the plant model, despite significant correlations with the cold stenotherm Dytiscidae species richness.

Total richness patterns (eurytherm and stenotherm species pooled) for the three taxonomic groups did not differ much from the ones observed for the cold stenotherm species (Table 2), except, of course, the relation with altitude. Altitude, pond area and presence of macrophyte were also strongly correlated to total species richness of the different taxonomic groups and selected as predictive variables in the GAM models.

\section{Discussion}

Cold stenotherm species were present in all studied alpine or subalpine ponds, even if the number of Dytiscidae and Odonata species per pond was always low $(\leq 2)$. However, only a small proportion of the 

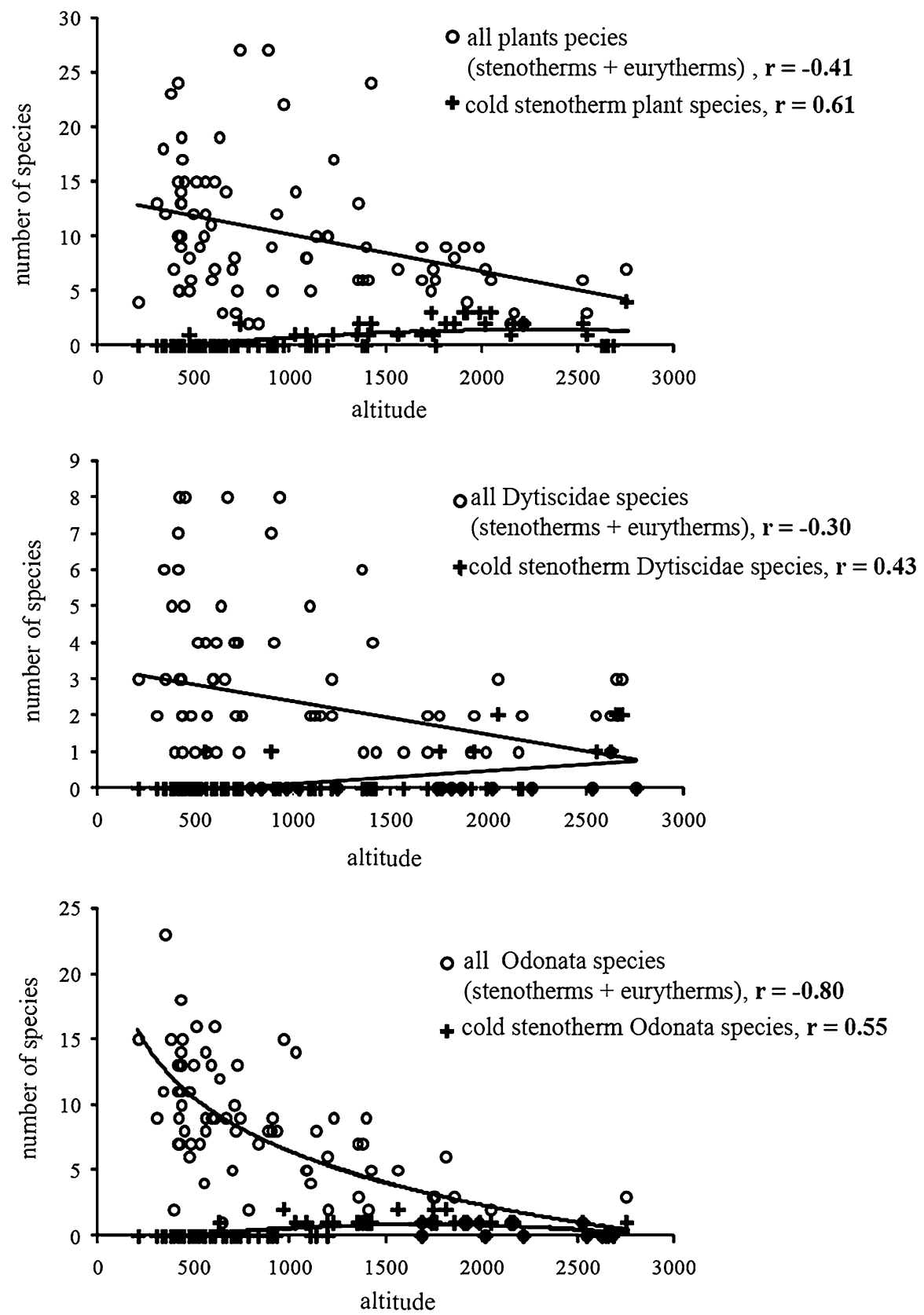

Fig. 1 Richness of cold stenotherm species and of all species (stenotherms + eurytherms) for plant, Coleoptera Dytiscidae and Odonata in relation with altitude along the Swiss elevation

species classified as cold stenotherm by Rosset \& Oertli (2011) were found. If cold stenotherm species richness patterns varied between the different taxonomic groups, few differences in the responses to the different environmental variables could be detected between the cold stenotherm species richness and the gradient ( $n=86$ ponds). $r$ Spearman correlation coefficient between species richness and altitude. All relationships were significant

total species richness (stenotherm and eurytherm) of the same taxonomic group within the altitudinal range investigated. Total species richness and cold stenotherm species richness of a same taxonomic group were related to the same environmental drivers and followed similar trends along the different 


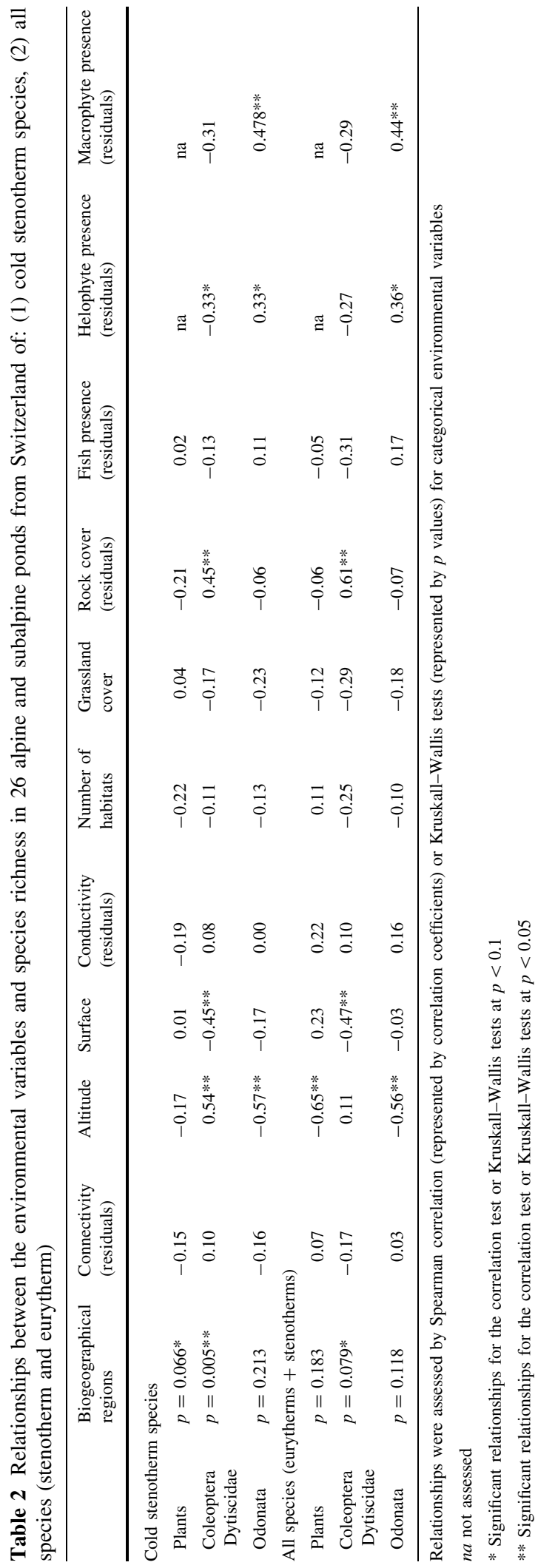

environmental gradients. This underlines the likely lack of specific environmental requirement for cold stenotherm communities.

Interactions of environmental factors acting at different geographical scales (ranging from the biogeographical to regional and local) explain the biodiversity patterns in small alpine waterbodies (Catalan et al., 2009a).

Kernan et al. (2009) showed that species distribution in alpine waterbodies was strongly related to geographical regions. Despite the smaller scale of our study, we also found that cold stenotherm Dytiscidae species richness and to a lesser extent cold stenotherm plant species richness patterns varied across biogoegraphical regions in the Swiss Alps. However, this geographical pattern could also be partly induced by the rather small size of our dataset that may have prevented us from sampling all types of alpine ponds of a given region.

At the regional scale, altitude is considered as a main driver of alpine pond vegetation and macroinvertebrate richness (Oertli et al., 2002, 2005). Benthic communities are shown to become less diverse with altitude, leading to a species richness decrease with higher elevation (Oertli et al., 2008; this study). Overall cold stenotherm species richness was, on the contrary, increasing with altitude along the whole Swiss altitudinal range, confirming that the species selected as cold stenotherm are mainly restricted to mountain areas and well adapted to the harsh environmental conditions prevailing in alpine ponds.

However, at the smaller altitudinal scale of the subalpine and alpine range, species richness patterns differed between the three taxonomic groups of cold stenotherm species. Odonata and plant species richness decreased with altitude, in accordance with most studies dealing with species richness in alpine lakes and ponds (Hinden et al., 2005; Fjellheim et al., 2009; Čiamporová-Zatovičová et al., 2010). Cold stenotherm Dytiscidae richness was, on the contrary, positively correlated with altitude. This contrasts with the findings of Čiamporová-Zatovičová \& Čiampor, (2011) who found a hump-shaped response of aquatic Coleoptera richness to altitude in the Tatra Mountains, with the number of species being highest between 1,500 and $1,800 \mathrm{~m}$ a.s.l. A similar pattern probably also occur in the Swiss Alps; however, due to the scarcity of our data for ponds above 2,500 m. a.s.1., a 
Table 3 GAMs modelling the relationships between the species richness and selected environmental variables

\begin{tabular}{lccccccc}
\hline & D2 & COR & cvCOR & Altitude & Surface & $\begin{array}{l}\text { Macrophyte presence } \\
\text { (residuals) }\end{array}$ & $\begin{array}{l}\text { Rock cover } \\
\text { (residuals) }\end{array}$ \\
\hline Cold stenotherm species number & & & & & & \\
$\quad$ Plants & 0.34 & 0.62 & 0.30 & 57.00 & 43.00 & 0.00 & 0.00 \\
Coleoptera Dyticidae & 0.78 & 0.92 & 0.50 & 37.00 & 26.00 & 37.00 & 0.00 \\
$\quad$ Odonata & 0.47 & 0.66 & 0.57 & 41.00 & 0.00 & 59.00 & 0.00 \\
Total species number & & & & & & 0.00 & 0.00 \\
Plants & 0.45 & 0.80 & 0.52 & 57.00 & 43.00 & 0.00 \\
Coleoptera Dytiscidae & 0.52 & 0.83 & 0.62 & 19.00 & 27.00 & 52.00 & 0.00 \\
Odonata & 0.49 & 0.64 & 0.57 & 42.00 & 0.00 & 58.00 & 0.00 \\
\hline
\end{tabular}

$\mathrm{D} 2$, validation (COR) and cross-validation (cvCOR) are specified. Contributions of the variables to the model are expressed in $\%$

Fig. 2 Response functions for cold stenotherm plant, Dytiscidae and Odonata species richness on the environmental variables incorporated in their respective GAMs in the studied altitudinal range. The dashed lines are approximate $95 \%$ confidence intervals around the smooth function

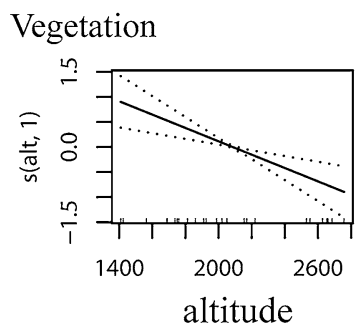

Coleoptera

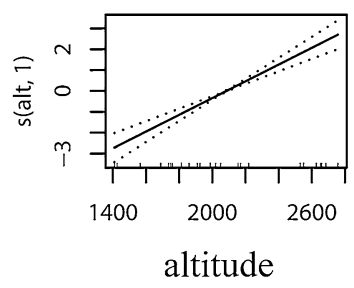

Odonata

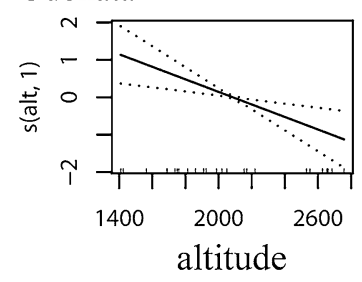

negative relation between altitude and number of cold stenotherm Dytiscidae species could not be detected.

Beside altitude, regional connectivity also plays an important part in high altitude pond biodiversity. These remote ecosystems can be regarded as stepping stones and most of the colonizing species are recruited from nearby water bodies (Fjellheim et al., 2009). This is consistent with the results of Oertli et al. (2008),

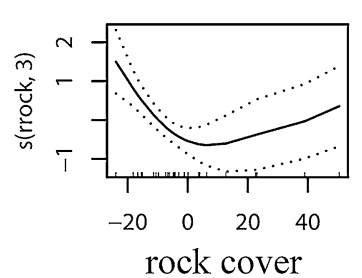

(residuals)
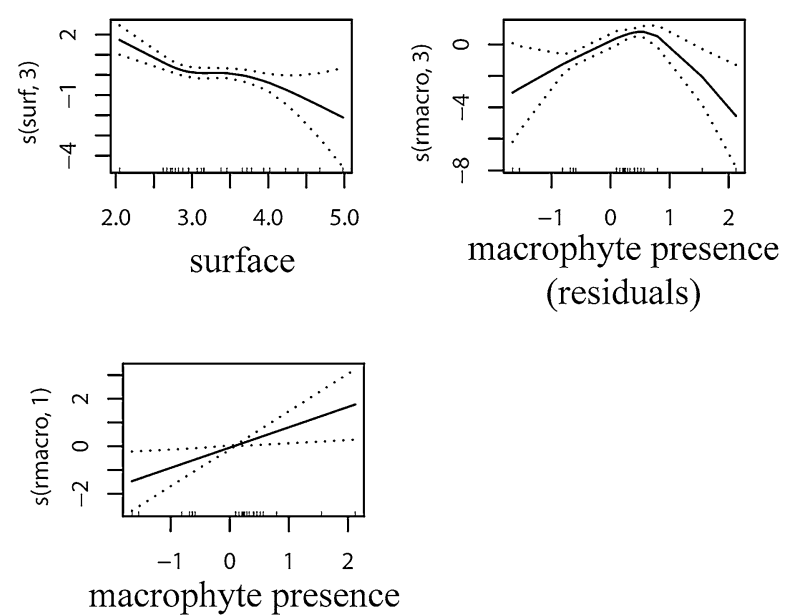

(residuals)

who found that connections through tributaries and/or small distances between ponds structured pond macroinvertebrates communities in a small alpine circle in the Swiss National Park. Surprisingly, no effect of connectivity on plant or macroinvertebrate cold stenotherm species richness could be detected in our study. However, our connectivity index is based on the distances and areas of the neighbouring water bodies 
and do not take into account the habitat suitability or the permeability of the surrounding landscape matrix for a given species or taxonomic groups.

At local scale, habitat size may be an important driver of species richness with larger ponds supporting more species, as a result of higher colonization and lower extinction probabilities (Mac Arthur \& Wilson, 1967) or increased habitat diversity (Catalan et al., 2009b). However, studies linking species richness with pond size evidenced contrasting results. For lowland ponds, Oertli et al. (2002) found positive relationships between area and species richness only for selected taxonomic groups including aquatic vegetation and Odonata, whereas the relations were not significant for other groups such as the Coleoptera (Oertli et al., 2002). For alpine ponds, no significant relationship between macroinvertebrate or macrophyte species richness and pond size could be found by Hinden et al. (2005) and Martínez-Sanz et al. (2012). However, Čiamporová-Zatovičová \& Čiampor (2011) observed a hump-shaped relation between coleopteran and pond area in the Tatra Mountains and attributed this observation to differences in vegetation cover and number of habitats found in ponds of different size. In our study, both cold stenotherm and total Dytiscidae species richnesses were negatively related to pond area. This relation may be linked to fish presence, as larger ponds in the Swiss Alps are often stocked with fishes and a strong correlation between pond size and fish presence was already shown in this study. The correlation between Dytiscidae species richnesses and fish presence were negative and close to the significance level in our study, also indicating some predation pressure by fish. Furthermore, negative influence of fishes on macroinvertebrate communities have already been observed in alpine ponds and lakes (Knapp et al., 2001; Hinden et al., 2005; Martínez-Sanz et al., 2012).

Among the biotic drivers of alpine pond biodiversity, vegetation, in the form of macrophyte and to a lesser extent helophyte presence, also influenced cold stenotherm fauna richness in our study. Cold stenotherm Odonata species were positively correlated with the presence of submerged, floating or emerging aquatic vegetation. Other studies on alpine ponds also showed the importance of aquatic vegetation for macroinvertebrate diversity (Hinden et al., 2005; Mendoza \& Catalan, 2010). Aquatic vegetation can lead to an increase the prey availability for Odonata
(Lombardo, 1997), but also provide habitat resource and refugee against fish (Mendoza \& Catalan, 2010). Although the effects of biotic interactions on cold stenotherm species were not explored further in this study it is important to underline that these relations may be highly sensitive to climate change (Brook et al., 2008), leading to extinctions cascades with larger species and predators being especially at risk (Eklöf et al., 2012). However, alongside with local extinctions of cold stenotherm species, climate change will also lead to the colonization of new species, in alpine ponds (Rosset et al., 2010; Rosset \& Oertli, 2011). Changes in the community structures will therefore depend on whether the regional species pool contains functionally redundant species that differ in their environmental tolerances (Thompson \& Shurin, 2012).

\section{Conclusions}

Our results confirmed the specificity of the set of environmental variables governing pond biodiversity in altitude. Some key variables for lowland pond biodiversity have an inconspicuous rule in altitude, as for example the size of the waterbody. Other variables are on the contrary important drivers both in lowland and alpine ponds, such as the presence of aquatic vegetation. This underlines therefore that the management of pond and its biodiversity has to be 'altitude-specific', with obviously new procedures or rules to create or develop.

Nevertheless, our results indicate that the cold stenotherm communities from the alpine ponds do not show some specific requirement if compared to the other species belonging to the same taxonomic groups inhabiting the same pond. Therefore, management measures would probably have the same impact on stenotherm species than on the others. Both total and cold stenotherm species richness could be favoured by a same set of measures.

Pond creation and restoration actions promoted by local nature conservation associations (e.g. habitats valorization for pedagogic purposes) or local authorities in charge of nature conservation (e.g. compensation measures) are frequent in the Swiss Alps. On the bases of our results, pond restoration and creation action should ideally be located along a gradient between 2,000 and 3,000 $\mathrm{m}$ a.s.1., a range critical for 
present and future migration of cold stenotherm species. These ponds do not necessarily need to be of large size but some of them should present morphological features favouring the development of aquatic vegetation, which is often lacking in alpine areas.

In the context of climate warming, where boreoalpine species may have to colonize higher areas, corridors favouring the biological connectivity could facilitate the species' upward dispersal. We therefore encourage studies on this topic: there is still a lack of knowledge on the dispersal of cold stenotherm species through the alpine landscape and on their colonization of new alpine habitats. This information is crucial for conservation of alpine freshwater biodiversity faced to climate warming.

Acknowledgments This study was carried out in the framework of the RestorAlps project supported by the University of Applied Sciences Western Switzerland (competence network 'RealTech') and the Canton of Valais. We thank the numerous people from the University of Geneva (Laboratory of Ecology and Aquatic Biology) and the University of Applied Sciences of Western Switzerland (hepia, Geneva) for the field-work, the laboratory-work and the database management. Various additional supports contributed for gathering the database for the 26 ponds studied: the Federal Office for the Environment (OFEV), several Swiss Cantons, the University of Geneva (Laboratory of Ecology and Aquatic Biology), and the Research Commission of the Swiss National Park.

\section{References}

Biggs, J., A. Corfield, D. Walker, M. Whitfield \& P. Williams, 1994. New approaches to the management of ponds. British Wildlife 5: 273-287.

Brook, B. W., N. D. Sodhi \& C. J. A. Bradshaw, 2008. Synergies among extinction drivers under global change. Trends in Ecology and Evolution 23: 453-460.

Catalan, J., C. J. Curtis \& M. Kernan, 2009a. Remote European mountain lake ecosystems: regionalisation and ecological status. Freshwater Biology 54: 2419-2432.

Catalan, J., M. G. Barbieri, F. Bartumeus, P. Bitušík, i. Botev, A. Brancelj, D. Cogălniceanu, M. Manca, A. Marchetto, N. Ognjanova-Rumenova, S. Pla, M. Rieradevall, S. Sorvari, E. Štefková, E. Stuchlík \& M. Ventura, 2009b. Ecological thresholds in European alpine lakes. Freshwater Biology 54: 2494-2517.

Čiamporová-Zaťovičová, Z. \& F. Čiampor Jr., 2011. Aquatic beetles of alpine lakes: diversity, ecology and small-scale population genetics. Knowledge and Management of Aquatic Ecosystems 402: 10.

Čiamporová-Zaťovičová, Z., L. Hamerlík, F. Šporka \& P. Bitušík, 2010. Littoral benthic macroinvertebrates of alpine lakes (Tatra Mts) along an altitudinal gradient: a basis for climate change assessment. Hydrobiologia 648: 19-34.

Eklöf, A., L. Kaneryd \& P. Münger, 2012. Climate change in metacommunities: dispersal gives double-sided effects on persistence. Philosophical Transactions of the Royal Society B 267: 2945-2954.

Fjellheim, A., G. G. Raddum, V. Vandvik, D. Cogălniceanu, A. Boggero, A. Brancelj, J. Galas, F. Šporka, Y. Vidinova, P. Bitusšík, E. Dumnicka, N. Gâldean, A. Kownacki, I. Krno, E. Preda, G. Ríşnoveanu \& E. Stuchlík, 2009. Diversity and distribution patterns of benthic invertebrates along alpine gradients. A study of remote European freshwater lakes. Advances in Limnology 62: 167-190.

Füreder, L., R. Ettinger, A. Boggero, B. Thaler \& H. Thies, 2006. Macroinvertebrate diversity in Alpine lakes: effects of altitude and catchment properties. Hydrobiologia 562: 123-144.

Gee, J. H. R., B. D. Smith, K. M. Lee \& S. W. Griffiths, 1997. The ecological basis of freshwater pond management for biodiversity. Aquatic Conservation Marine and Freshwater Ecosystems 7: 91-104.

Gonseth, Y., T. Wohlgemuth, B. Sansonnens \& A. Buttler, 2001. Régions biogéographique de Suisse - Explications et divisions standards. Cahier de l'Environnement, Swiss Federal Office of the Environment, Forest and Landscape (OFEFP), Berne, Switzerland.

Hastie, T. J. \& R. J. Tibshirani, 1990. Generalized Additive Models. Chapman \& Hall, London.

Hinden, H., B. Oertli, D. Auderset Joye, R. Juge, N. Menetrey, L. Sager \& J. B. Lachavanne, 2005. Alpine ponds biodiversity: what are the related environmental variables? Aquatic Conservation 15: 613-624.

Humbert-Droz, H., 2000. Evaluation du rôle de la connectivité comme facteur de régulation de la biodiversité des petits plans d'eau. Master thesis, University of Geneva.

Kernan, M., M. Ventura, P. Bitušík, A. Brancelj, G. Clarke, G. Velle, G. G. Raddum, E. Stuchlík \& J. Catalan, 2009. Regionalisation of European mountain lake ecosystems according to their biota: environmental versus geographical patterns. Freshwater Biology 54: 2470-2493.

Knapp, R. A., K. R. Matthews \& O. Sarnelle, 2001. Resistance and resilience of alpine lake fauna to fish introductions. Ecological Monographs 71: 401-421.

Krajick, K., 2004. All downhill from here? Science 303: 1601-1602.

Lehmann, A., J. M. Overton \& J. R. Leathwick, 2002. GRASP: generalized regression analysis and spatial prediction. Ecological Modelling 157: 189-207.

Lombardo, P., 1997. Predation by Enallagma nymphs (Odonata, Zygoptera) under different conditions of spatial heterogeneity. Hydrobiologia 356: 1-9.

Mac Arthur, R. \& E. O. Wilson, 1967. The Theory of Island Biogeography. Princeton University Press, Princeton, NJ.

Martínez-Sanz, C., C. Fernández-Aláez \& F. García-Criado, 2012. Richness of littoral macroinvertebrate communities in mountain ponds from NW Spain: what factors does it depend on? Journal of Limnology 71: 154-163.

Mendoza, G. \& J. Catalan, 2010. Lake macroinvertebrates and the altitudinal environmental gradient in the Pyrenees. Hydrobiologia 648: 51-72. 
Moser, D. M., A. Gygax B. Bäumler, N. Wyler \& R. Palese, 2002. Liste rouge des espèces menacées de Suisse. Fougères et plantes à fleurs. Office fédéral de l'environnement, des forêts et du paysage: Berne; Centre du Réseau Suisse de Floristique, Chambésy; Conservatoire et Jardin botaniques de la Ville de Genève, Chambésy.

Oertli, B. \& P.-A. Frossard, 2013. Les mares et étangs : écologie, conservation, gestion, valorisation. Presses Polytechniques Universitaires Romandes, Lausanne.

Oertli, B., D. Auderset Joye, E. Castella, R. Juge \& J-B. Lachavanne, 2000. Diversité biologique et typologie écologique des étangs et petits lacs de Suisse. Final report, OFEFP and University of Geneva.

Oertli, B., D. Auderset Joye, E. Castella, R. Juge, D. Cambin \& J.-B. Lachavanne, 2002. Does size matter? The relationship between pond area and biodiversity. Biological Conservation 104: 59-70.

Oertli, B., D. Auderset Joye, E. Castella, R. Juge, A. Lehmann \& J.-B. Lachavanne, 2005. PLOCH: a standardized method for sampling and assessing the biodiversity in ponds. Aquatic Conservation: Marine and Freshwater Ecosystems 15: 665-679.

Oertli, B., N. Indermuehle, S. Angelibert, H. Hinden \& A. Stoll, 2008. Macroinvertebrate assemblages in 25 high alpine ponds of the Swiss National Park (Cirque of Macun) and relation to environmental variables. Hydrobiologia 597: 29-41.

Parolo, G. \& G. Rossi, 2008. Upward migration of vascular plants following a climate warming trend in the Alps. Basic and Applied Ecology 9: 100-107.

R Development Core Team, 2012. R: A Language and Environment for Statistical Computing. R Foundation for Statistical Computing, Vienna, Austria. http://www.R-project.org

Rosset, V. \& B. Oertli, 2011. Freshwater biodiversity under climate warming pressure: identifying the winners and losers in temperate standing waterbodies. Biological Conservation 144: 2311-2319.
Rosset, V., A. Lehmann \& B. Oertli, 2010. Warmer and richer? Predicting the impact of climate change on biodiversity in small temperate waterbodies. Global Change Biology 16: 2376-2387.

Sala, O., F. Stuart Chapin III, J. J. Armesto, E. Berlow, J. Bloomfield, R. Dirzo, E. Huber-Sanwald, L. F. Huenneke, R. B. Jackson, A. Kinzig, R. Leemans, D. M. Lodge, H. A. Mooney, M. Oesterheld, N. L. M. T. Poff, B. H. Walker, M. Walker \& D. H. Wall, 2000. Global biodiversity scenarios for the year 2100. Science 287: 1770-1774.

Sharma, C. M., S. Suyal, S. Gairola \& S. K. Ghildiyal, 2009. Species richness and diversity along an altitudinal gradient in moist temperate forest of Garhwal Himalaya. Journal of American Science 5: 119-128.

Thompson, P. L. \& J. B. Shurin, 2012. Regional zooplankton biodiversity provides limited buffering of pond ecosystems against climate change. Journal of Animal Ecology 81: 251-259.

Thuiller, W., S. Lavorel \& M. B. Araújo, 2005. Niche properties and geographical extent as predictors of species sensitivity to climate change. Global Ecology and Biogeography 14: 347-357.

Vittoz, P., J. Bodin, S. Ungricht, A. Conradin \& G.-R. Walther, 2008. One century of vegetation change on Isla Persa, a nunatak in the Bernina massif of the Swiss Alps. Journal of Vegetation Sciences 19: 671-680.

Williams, P., J. Biggs, M. Whitfield, A. Thorne, S. Bryant, G. Fox \& P. Nicolet, 1999. The Pond Book: A Guide to the Management and Creation of Ponds. Ponds Conservation Trust, Oxford.

Woodward, G., D. M. Perkins \& L. E. Brown, 2010. Climate change and freshwater ecosystems: impacts across multiple levels of organization. Philosophical Transactions of the Royal Society B 12: 2039-2106.

Yoccoz, N. G., A. Delestrade \& A. Loison, 2010. Impact of climatic change on alpine ecosystems: inference and prediction. Journal of Alpine Research 98: 355-366. 